\title{
THE TOXICITY OF MAULI BANANA (MUSA ACUMINATA) STEM WATER EXTRACT ON BONE MARROW MESENCHYMAL STEM CELL IN VITRO
}

\author{
AMY NINDIA CARABELLY*, DIDIT ASPRIYANTO, MAHARANI LAILLYZA APRIASARI, SELVIANA RIZKY \\ Department of Oral Biology, Faculty of Dentistry, University of Lambung Mangkurat, Banjarmasin, Indonesia. Email: acarabelly@gmail.com \\ Received 02 October 2018, Revised and Accepted 25 February 2019
}

ABSTRACT

Objective: Since mesenchymal stem cells (MSC) can differentiate into bone, cementum, and periodontal ligament, they can be used to treat aggressive periodontitis. The limited number of MSCs requires replenishment of growth factor in the cell culture process. Since growth factor is quite expensive, an alternative material is needed. Mauli banana stem has antioxidant and immunomodulatory properties. Methanol extract of Mauli banana stem is known to be toxic toward MSCs; therefore, another solvent with a non-toxic effect is needed, such as a water solvent. We analyzed the toxicity of Mauli banana stem water extract on MSC in vitro.

Methods: In this laboratory experimental (true experimental) study with a Post-test Only Control Group Design, MSC cultures were treated with Mauli banana stem water extract at 10,20,40,60,80, and $100 \mathrm{mg} / \mathrm{mL}$ dosages. One group without any treatment served as a control group and one was a media control group. Each group was incubated for $24 \mathrm{~h}$ and then was given 3-(4,5-dimethylthiazol-2-yl)-2,5-diphenyltetrazolium bromide reagent and analyzed by an enzyme-linked immunosorbent assay (ELISA) reader.

Results: One-way analysis of variance showed a significant difference.

Conclusion: Mauli banana stem water extracts at 10, 20, 40, and $60 \mathrm{mg} / \mathrm{mL}$ were not toxic toward MSC in vitro, while dosages of 80 and $100 \mathrm{mg} / \mathrm{mL}$ dosage were toxic.

Keywords: Mauli banana stem extract, Mesenchymal stem cell, Toxicity.

(C) 2019 The Authors. Published by Innovare Academic Sciences Pvt Ltd. This is an open access article under the CC BY license (http://creativecommons. org/licenses/by/4. 0/) DOI: http://dx.doi.org/10.22159/ijap.2019.v11s1.16762

\section{INTRODUCTION}

Aggressive periodontitis is that which advances progressively in young patients, defined by the rapid loss of attachment [1]. This lesion is treated using bone graft. Bone graft is known to regenerate only half of the destroyed periodontal tissue, so the therapeutic approach has shifted to the use of stem cells for treatment [2,3]. Mesenchymal stem cells (MSCs) can differentiate into bone, cementum, and periodontal ligament, which enables their use for the treatment of aggressive periodontitis [4,5]. However, there is only one MSC per 10,000 nucleated cells, so a growth factor is necessary in addition to the cell culture process [6]. Growth factor is an exogenous material required for activation of the cell proliferation pathway so that the appropriate cell culture amount can be established. Exogenous phytochemical materials that found in herbal plant extracts can be used as an alternative growth factor to increase the number of MSCs. One such material is Mauli banana stem.

Mauli banana stem extract has the highest bioactive content of tannin $(67.59 \%)$, followed by saponin $(14.49 \%)$, alkaloid $(3.44 \%)$, ascorbic acid $(0.44 \%)$, flavonoid $(0.25 \%)$, and lycopene $(0.006 \%)$ [7]. Mauli banana stem extract is an antioxidant with the activity to bind heavy metal iron, hydrogen peroxide, and hydroxyl to decrease reactive oxygen species (ROS) [7,8]. ROS are secondary messengers in the intracellular signaling pathway, which regulates cell proliferation [9].

Mauli banana stem extract has the highest content of tannin having a polar property, so it can be dissolved in glycerol, alcohol, water, and acetone [7,10]. Carabelly et al.[11] proved that methanol extract of Mauli banana stem is toxic toward MSC. Hosein and Zinab [12] stated that tannin content extracted using methanol solvent is higher than that extracted using water solvent. We analyzed the toxicity of Mauli banana stem water extract on MSC in vitro. This study is expected to result in a standard dosage to be used for herbal medicine development of Mauli banana stem, which can be used as an alternative for growth factor to increase MSC numbers in vitro. This alternative agent is expected to be applied as alveolar bone destruction therapy in patients with aggressive periodontitis.

\section{METHODS}

Ethical clearance and permission to conduct this laboratory experimental study with a Post-test Only Control Group Design was obtained from the Ethics Committee of the Faculty of Dentistry, Lambung Mangkurat University (No.040/KEPKG-FKGULM/EC/IX/2017).

Mauli banana stem (SMK-PP Banjarbaru, South Kalimantan, Indonesia) was taken from a $10 \mathrm{~cm}$ root bump, was washed, was cut, and was placed in an oven at $60^{\circ} \mathrm{C}$. Then, the dried Mauli banana stem was mashed using a blender and filtered with 35 mesh filter, was weighed to $50 \mathrm{~g}$, and then was placed in a beaker glass to which $1000 \mathrm{~mL}$ Aquades was added and then heated to $50^{\circ} \mathrm{C}$ for $5 \mathrm{~h}$. Then, it was stirred 3 times using a 500 revolution per minute stirrer at the beginning, middle, and near end of the heating process. The sample was cooled, was filtered, and was placed into an evaporator at $60^{\circ} \mathrm{C}$ for $2 \times 24 \mathrm{~h}$. After evaporation, the sample was placed in a $60^{\circ} \mathrm{C}$ water bath until viscous extract was obtained.

MSCs with $80 \%$ confluency were distributed in a 96-wheel microplate and divided into six treatment groups. Groups 1-4 consisted of MSCs given Mauli banana stem extract at 10, 20, 40, 60, 80, and $100 \mathrm{mg} / \mathrm{mL}$ dosages. Group 7 was not given any treatment (control group) and Group 8 was a media control. Each group was repeated 5 times. The microplate was incubated for $24 \mathrm{~h}$, and then, the cells were washed with PBS and $25 \mu \mathrm{L}$ 3-(4,5-dimethylthiazol-2-yl)-2,5-diphenyltetrazolium reagent was added to each wheel. Then, the cells were incubated for 


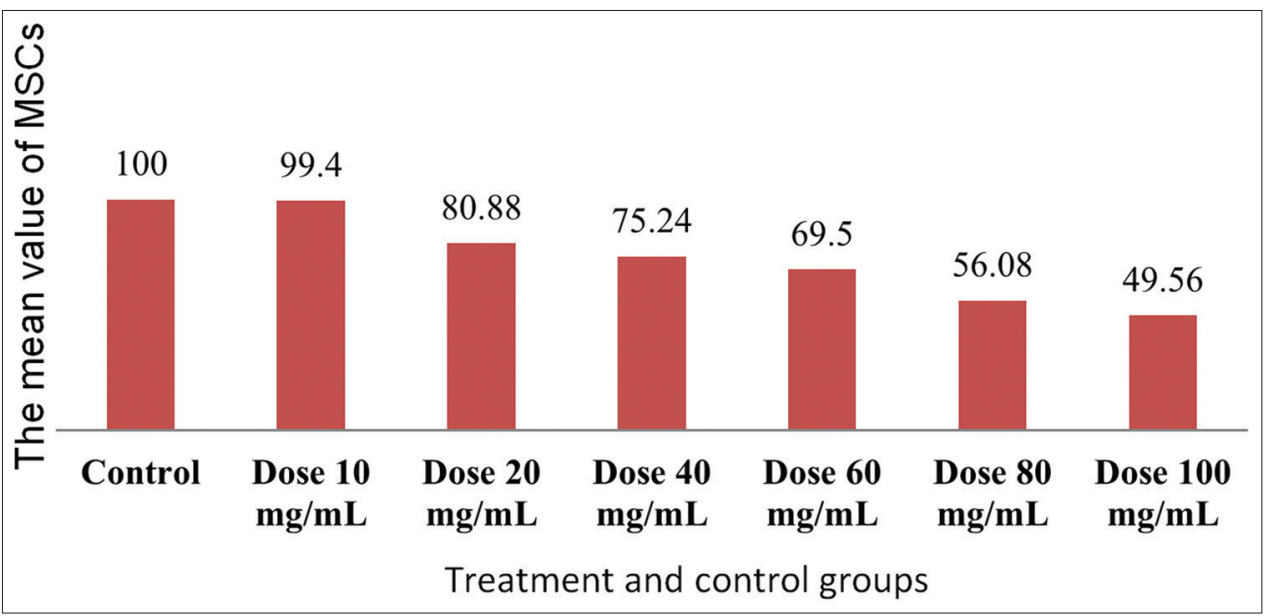

Fig. 1: Mean value of mesenchymal stem cells viability after Mauli banana water extract treatment

Table 1: Mean OD analyzed using the Games-Howell post hoc test between MSCs groups after treatment with Mauli banana stem water extract

\begin{tabular}{llllllll}
\hline Treatment Group & Control & Dose $\mathbf{1 0} \mathbf{~ m g} / \mathbf{m L}$ & Dose $\mathbf{2 0} \mathbf{~ m g} / \mathbf{m L}$ & Dose $\mathbf{4 0} \mathbf{~ m g} / \mathbf{m L}$ & Dose 60 mg/mL & Dose 80 mg/mL & Dose 100 mg/mL \\
\hline Control & & -0.003 & $-0.944^{*}$ & $-0.121^{*}$ & $-0.149^{*}$ & $-0.215^{*}$ & $-0.247^{*}$ \\
Dose $10 \mathrm{mg} / \mathrm{mL}$ & 0.003 & & $-0.090^{*}$ & $-0.117^{*}$ & $-0.145^{*}$ & $-0.211^{*}$ & $-0.243^{*}$ \\
Dose $20 \mathrm{mg} / \mathrm{mL}$ & $0.944^{*}$ & $0.090^{*}$ & & $-0.027^{*}$ & $-0.055^{*}$ & $-0.121^{*}$ & $-0.152^{*}$ \\
Dose $40 \mathrm{mg} / \mathrm{mL}$ & $0.121^{*}$ & $0.117^{*}$ & $0.027^{*}$ & & $-0.028^{*}$ & $-0.094^{*}$ & $-0.125^{*}$ \\
Dose $60 \mathrm{mg} / \mathrm{mL}$ & $0.149^{*}$ & $0.145^{*}$ & $0.055^{*}$ & $0.028^{*}$ & & $-0.066^{*}$ & $-0.097^{*}$ \\
Dose $80 \mathrm{mg} / \mathrm{mL}$ & $0.215^{*}$ & $0.211^{*}$ & $0.121^{*}$ & $0.094^{*}$ & $0.066^{*}$ & & $-0.031^{*}$ \\
Dose $100 \mathrm{mg} / \mathrm{mL}$ & $0.247^{*}$ & $0.243^{*}$ & $0.152^{*}$ & $0.125^{*}$ & $0.097^{*}$ & 0.031 & \\
\hline
\end{tabular}

${ }^{*} \mathrm{p}>0.05$, no significant difference

$4 \mathrm{~h}$ at $37^{\circ} \mathrm{C}$. After $4 \mathrm{~h}$, the medium in the microplate was removed and replaced with dimethyl sulfoxide $200 \mu \mathrm{L} /$ wheel. Then, the result was analyzed using an enzyme-linked immunosorbent assay (ELISA) reader with $595 \mathrm{~nm}$ wavelength.

\section{RESULTS}

The ELISA reader showed the optical density (OD) rate of the MSCs given Mauli banana stem water extract in each treatment and control group. Based on OD, the agent was said to be non-toxic if the cell viability percentage was $>60 \%$. Cell viability was calculated using the following formula [13]:

$$
\text { Cell viability }(\%)=\frac{\text { ODtreatment }- \text { OD media control }}{\text { ODcellontrol }- \text { ODmediacontrol }} \times 100 \%
$$

Figure 1 shows that Mauli banana stem water extracts at 10, 20, 40, and $60 \mathrm{mg} / \mathrm{mL}$ were not toxic toward MSC in vitro, while dosages of 80 and $100 \mathrm{mg} / \mathrm{mL}$ were toxic. A one-way analysis of variance test revealed a significant difference. Hence, a Games-Howell post hoc test showed no significant difference between $10 \mathrm{mg} / \mathrm{mL}$ Mauli banana stem water extract and the control group Table 1. Therefore, the effective dosage of Mauli banana stem water extract that is not toxic toward MSC in vitro was $10 \mathrm{mg} / \mathrm{mL}$.

\section{DISCUSSION}

Our results showed that Mauli banana stem water extracts at 10, 20, 40 , and $60 \mathrm{mg} / \mathrm{mL}$ dosages were not toxic toward MSC in vitro, while dosages of 80 and $100 \mathrm{mg} / \mathrm{mL}$ were toxic. This result differs from that of Carabelly et al. [11], which showed that methanol extract of Mauli banana stem is toxic toward MSC. The difference in solvent choice influenced the number of extracts produced. Hosein and Zinab [12] stated that the tannin content in methanol extract is higher than that of water extract. Romadanu et al. [14] also stated that an extraction using methanol as the solvent has the highest yield. The high yield found in methanol solvent showed that this solvent can extract more bioactive components with higher polarity. Mauli banana stem extract has the highest content of tannin having a polar property $[7,10]$. Mauli banana stem extract using methanol solvent can extract more bioactive tannin component compared to water solvent. Based on the study of Ashok and Upadhayaya [15], tannin at high dose can cause toxic effects on the cells. High-dose tannin has pro-oxidant properties, so it can increase ROS $[16,17]$. The increased ROS activity can activate p53, so cell apoptosis can occur [18]. Tannin also is known for its property to increase Erk, which activates p53 for the apoptosis pathway through elevation of transcription among certain proapoptotic Bcl families, especially Bax $[19,20]$. Other than the difference in solvent choice, the difference in Mauli banana stem extract dosages also showed different toxicity results toward MSC in vitro.

Mauli banana stem extract has antioxidant properties, so it can decrease ROS $[7,8]$. ROS are secondary messengers in the intracellular signaling pathway, which regulates cell proliferation, differentiation, and apoptosis [9]. The effect of ROS on cell function depends on the dosage. At high dose, ROS can endanger the life of the cell and disturb physiologic function. However, ROS at low dosage also are important for cell signaling because it can modify redox-sensitive protein, which is involved in cell proliferation and differentiation [9]. The decreased ROS number caused by Mauli banana stem extract can activate the cell proliferation pathway directly or through the mitogen-activated protein kinase (MAPK) and Akt pathways [9,21].

Mauli banana stem extract has the highest bioactive content of tannin (67.59\%) [7]. Mauli banana has the proanthocyanidin type of tannin (condensed tannin) [22], which can induce tyrosine phosphorylation in tyrosine kinase insulin receptors on the surface of MSCs to activate the MAPK/Erk and phosphoinositide 3-kinase (PI3K)/Akt/mTOR pathways [20,21,23,24]. Based on the study of Haston et al. [25], pERK1/2 staining can be detected in the marginal zone of Sox $2+$ stem cells, which shows that MAPK/Erk has a role in stem cell proliferation. Meanwhile, the PI3K pathway also has an important role for MSC 
mitogenesis, proliferation, apoptosis prevention, and multipotent maintenance [26]

\section{CONCLUSION}

Mauli banana stem water extract at $10,20,40$, and $60 \mathrm{mg} / \mathrm{mL}$ dosages is not toxic toward MSC in vitro, while dosages of 80 and $100 \mathrm{mg} / \mathrm{mL}$ dosage are toxic.

\section{CONFLICTS OF INTEREST}

The authors declare that there are no conflicts of interest.

\section{REFERENCES}

1. Herawati D. Combination therapy for root debridement and antibiotics against aggressive periodontitis. Majalah Kedokt Gigi Indones 2011;18 Suppl 2:200-4.

2. Newman MG, Takei HH, Carranza FA. Carranza's Clinical Periodontology. Maryland Heights, MO: Elsevier Health Science; 2012. p. 429

3. Alpiste Illueca FM, Buitrago Vera P, de Grado Cabanilles P, Fuenmayor Fernandez V, Gil Loscos FJ. Periodontal regeneration in clinical practice. Med Oral Patol Oral Cir Bucal 2006;11:E382-92.

4. Jain A, Agarwal A, Gokhale ST, Manjunath S, Mishra N. Periodontal ligament stem cell: An update. J Adv Clin Res 2014;1:20-2.

5. Kawaguchi H, Hirachi A, Hasegawa N, Iwata $T$, Hamaguchi $H$, Shiba $\mathrm{H}$, et al. Enhancement of periodontal tissue regeneration by transplantation of bone marrow mesenchymal stem cells. J Periodontol 2004; $75: 1281-7$

6. Stolzing A, Jones E, McGonagle D, Scutt A. Age-related changes in human bone marrow-derived mesenchymal stem cells: Consequences for cell therapies. Mech Ageing Dev 2008;129:163-73.

7. Apriasari ML, Iskandar T, Suhartono E. Bioactive compounds and antioxidant activity of methanol extract mauli bananas (Musa Sp) stem. Int J Biosci Biochem Bioinform 2014;4 Suppl 2:110-5.

8. Noor WF, Aprianti N, Saputra SR, Apriasari ML, Suhartono E. Oxidative stress on buccal mucosa wound in rat and rule of topical application of ethanolic extract of maulibanana (Muca acuminata) stem. J Trop Life Sci 2015;5 Suppl 2:84-7.

9. Son Y, Cheong YK, Kim NH, Chung HT, Kang DG, Pae HO, et al. Mitogen-activated protein kinases and reactive oxygen species: How can ROS activate MAPK pathways? J Signal Transduct 2011;2011:792639.

10. Artati, Kriswiyanti E, Fadilah. Effect of stirring rotational speed and operating temperature on tannin extraction from cashew with acetone solvent. Ekuilibrium 2007;6 Suppl 1:33-8.

11. Carabelly AN, Putra ST, Suardita K. The toxicity of methanol extract of mauli banana stem (Musa acuminate) against bone marrow mesenchymal stem cell in vitro. Dentino 2017;2 Suppl 1:24-8.
12. Hosein HK, Zinab D. Phenolic compounds and antioxidant activity of henna leaves extracts (Lawsonia inermis L.). World J Daily Food Serv 2007;2 Suppl 1:38-41

13. Freshney R. Culture Animal cell: A Manual of Basic Technique and Specialized Application. $6^{\text {th }}$ ed. New Jersey: John Wiley and Sons, Inc.; 2010. p. 187-94.

14. Romadanu, Rachmawati SH, Lestari SD. Test of activity antioxidant Nelumbo nucifera extract. J Fish Tech 2014;3 Suppl 1:1-7.

15. Ashok PK, Upadhayaya K. Tannins are astringents. J Pharmacogn Phytochem 2012;1 Suppl 3:45-9.

16. Ling LT, Palanisamy UD, Cheng HM. Prooxidant/antioxidant ratio (proantidex) as a better index of net free radical scavenging potential. Molecules 2010;15:7884-92.

17. Jordan LG. Tannic acid Crosslinked Collagen Type I for Prevention of Local HER2-Positive Breast Cancer Recurrent; 2016. Available from: https://www.tigerprints.clemson.edu/all_theses/2571/. [Last accessed on 2018 Jan 16].

18. Jaganathan SK, Mandal M. Involvement of non-protein thiols, mitochondrial dysfunction, reactive oxygen species and p53 in honeyinduced apoptosis. Invest New Drugs 2010;28:624-33.

19. Kumar V, Abbas AK, Aster J. Basic Pathology. Philadelphia, PA: Elsevier; 2017. p. 2-28.

20. Chi Z, Ma X, Cui G, Li M, Li F. Cinnamtannin B-1 regulates cell proliferation of spinal cord astrocytes and protects the cell from oxygen-glucose-serum deprivation/reoxygenation-induced apoptosis. Int J Mol Sci 2013;14:15827-37.

21. Sun X, Gao RL, Lin XJ, Xu WH, Chen XH. Panax notoginseng saponins induced up-regulation, phosphorylation and binding activity of MEK, ERK, AKT, PI-3K protein kinases and GATA transcription factors in hematopoietic cells. Chin J Integr Med 2013;19:112-8.

22. Yang J, Tan H, Zhai H, Wang Q, Zhao N, Cai Y, et al. Research on chemical composition and ensiling characteristics of banana stems and leaves. Adv Mater Res 2012;347:1647-51.

23. Ito Y, Pandey P, Place A, Sporn MB, Gribble GW, Honda T, et al. The novel triterpenoid 2-cyano-3,12-dioxoolean-1,9-dien-28-oic acid induces apoptosis of human myeloid leukemia cells by a caspase-8dependent mechanism. Cell Growth Differ 2000;11:261-7.

24. Taher M, Majid FA, Sarmidi MR. A proanthocyanidin from Cinnamomum zeylanicum stimulates phosphorylation of insulin reseptor in 3T3-L1 adipocytes. J Teknol 2006;44:53-68.

25. Haston S, Pozzi S, Carreno G, Manshaei S, Panousopoulos L, GonzalezMeljem JM, et al. MAPK pathway control of stem cell proliferation and differentiation in the embryonic pituitary provides insights into the pathogenesis of papillary craniopharyngioma. Development 2017; $144: 2141-52$

26. Chen J, Crawford R, Chen C, Xiao Y. The key regulatory roles of the $\mathrm{PI} 3 \mathrm{~K} /$ Akt signaling pathway in the functionalities of mesenchymal stem cells and applications in tissue regeneration. Tissue Eng Part B Rev 2013;19:516-28. 